\title{
Covering Islam in Western Media: From Islamic to Islamophobic Discourses
}

\author{
Bouchaib Benzehaf \\ Chouaib Doukkali University Morocco \\ bbenz841@gmail.com
}

\begin{abstract}
A fundamental role allocated to the media is the shaping of public opinion about topical issues, thus making the act of obtaining accurate and verified information a major challenge. In this context, Said (1997) argues that coverage of Islam by the media has always been lacking in subjectivity, and Arabs/Muslims have at best been obscured and at worst "othered" and demonized rather than revealed by the media. The 9/11 attacks have re-triggered an explosion of media coverage of Islam and Muslims with the terms "Muslim" and "Terrorist" becoming synonymous in many western countries. The attacks have been exploited to cause a social anxiety/panic toward Islam and Muslim cultures leading to Islamophobia which is being further reinforced in Trump's America. Situated within the framework of Said's Orientalism, which helps us understand the relationships between the West and the Muslim world and also framed by agenda-setting media theory, which explains how media manipulate public opinion, this paper argues that Islamophobia results from the way the news stories regarding Islam and Muslims are covered. In particular, these stories are media(ated) and thus distorted. The paper borrows tools from critical discourse analysis, particularly global meanings and lexicalization, to analyse selected examples of media(ted) coverage of Islam and Muslim stories from different media sources with the aim of offering a holistic review of the scope and nature of the coverage of Islam and Muslims. In light of the results, we suggest interfaith dialogue and intercultural education as measures that can bring about understanding and tolerance between different religious communities.
\end{abstract}

Keywords: Media(ation), othering, Islamophobia, CDA, intercultural education 


\section{INTRODUCTION}

Islamophobia can be defined as fear or hostility towards Islam and followers of Islamic religion. Such unjustified fear has contributed immensely to discrimination and hate of Muslims across the globe. The media have played a decisive role in this phenomenon. Taking advantage of its large target audience, the media have established and reinforced the unjustified fear and hate towards Islam and Muslims. The media have mediated the coverage of Islam and Muslims, and in so doing they have obscured Islam and Muslims rather than revealed them. The media have created barriers to the true understanding of Islam, with non-Muslim journalists, reporters and media analysts using the terms terrorism and Islam interchangeably. In this context, Said (1997) argues that coverage of Islam by the media has always been lacking in subjectivity. The act of obtaining accurate and verified information has, therefore, become a major challenge in this globalized world.

The media takes advantage of the fact that its audience is varied and inclusive of all ages and walks of life. The people, who lack adequate skills and qualifications, heavily rely on preconceptions passed to them by the media in an attempt to understand the globe (Revell, 2010). The media are used as the most important weapon to shape public opinion and cover realities by their censorship and selective process. Thus, people's sources of information are biased and mediated. The media agencies have mobilized armies of analysts and journalists whose job has been to defame and tarnish Islamic religion by associating it with terrorism, a social evil in the society (Khan, 2009). As such, these biased depictions of Islam and Muslims make Westerners, out of ignorance, contribute to Islamophobia.

Western media coverage of Islam and Muslims has always been cast in a negative light. According to Hafez (2000), Western mass media tend "to characterize Islam as a fanatic and violent religion cutting-off hands, repressing women, and representing a clear antagonism towards Western ideas of freedom, human rights and democracy" (p. 5). Investigating the representation of Islam and Muslims in media news discourse after the 9/11 terrorist attacks, Alazzany (2008) found that violence, threat, hate and evil constituted the dominant ideological themes, thus painting Islam and Muslims as a threat to global stability.

Examining media representation of Sunni-Shia relations, Douai and Lauricella (2014) reported that the news media portrayed tensions between Sunni and Shia Islam from the perspective of "war on terrorism". Along the same lines, Alghamdi (2015) used critical discourse analysis to examine Western media coverage of the 2011 Norway terrorist attacks. The main finding was that some western media authors, inaccurately and unjustly, jumped to the conclusion that Muslims and Islamic groups were responsible for the attacks. These writers manipulated language in a way that revealed "blind prejudice against Islam and Muslims".

Similarly, Törnberg and Törnberg (2016) examined patterns of representation around the words Muslim and Islam in a 105 million word corpus of a large Swedish Internet forum from 2000 to 2013. The results obtained showed that Muslims are portrayed as a homogeneous outgroup implicated in conflict, violence 
and extremism. Also, these characteristics are described as emanating from Islam. The researchers reported that these patterns are often more extreme versions of those previously found in analysis of traditional media. Along the same lines, Oboler (2016) reported that Facebook is being used to normalize Islamophobia. After a qualitative analysis of 349 posts on Facebook, Oboler found several themes that depict Muslims as manipulative, dishonest and a threat to security and to Western way of life. The Internet, therefore, was found to reinforce existing discourses in traditional media.

Western media did not spare defaming Islam and its prophet even in cartoons targeting children. When considering media's impact on young children, this is most compelling as it teaches young children how to behave. In this context, Schrag and Javidi (1997) argues that children's first stories teach them not only false concepts about the real world, but also the criteria to evaluate the truthfulness of later media accounts in light of what has been inculcated into them. Thus, young children, who lack prior experience with Eastern culture, are bound to learn from child films like Aladdin inaccurate stories about Arabs, that they are, for instance, commonly prone to violent rage upon smallest, most trivial things such as discovering a single apple has been stolen from their cart.

The present paper is a critical discourse analysis of selected examples of media(ted) coverage of Islam and Muslim stories with the aim of offering a holistic review of the scope and nature of the coverage of Islam and Muslims as well as the point of view from which the world is presented. These examples are taken from different media sources: television, newspapers and Internet. The paper ends with practical suggestions regarding the deconstruction of Islamophobia. In this regard, interfaith dialogue, intercultural education and use of the Internet as a platform for interacting and marketing alternative freeing stories are suggested because of their potential to bring about understanding and tolerance between different religious communities.

\section{THEORETICAL CONSIDERATIONS}

Said's theory of Orientalism (2003) constitutes a suitable framework for the understanding of the relationship that binds Westerners with Muslims. Orientalism refers to the inaccurate representations and perception of the Eastern world by the Western world. It reveals Eurocentric prejudice against Arab-Islamic peoples and their culture. It is built on a hierarchy of a European self which is strong, rational and masculine and an Eastern other which is weak, irrational, and feminine. Such polarization helped Europe to define itself by establishing and maintaining opposites and others. The west was everything that the East was not and vice versa. Said believes that besides the academy, the corporations, and the government, the media play a fundamental role in this regard (Said, 1981).

Orientalism explains that the West has historically constructed non-Western societies as the other, distant, sensual, passive, irrational, ... to define itself. In Covering Islam, Said (1981) points out that the view of Islam is still structured by the historical encounter between the West and the East, an encounter which was framed by passion, prejudice and political interests. Said also argues that Israel plays 
a mediating role in Western views of the Arab and Islamic world since its creation in 1948. In the same vein, Poole and Richardson (2006) argue that the press often construct Muslims through an Orientalist lens. Thus, a framework of US and THEM has been created which identifies Muslims as dangerous, terrorists and oppressive.

As we speak about coverage of Islam in the media, we also need to look at how media operate. While they are claimed to convey the reality, the media, in fact, construct the reality. By mediating the news, the media choose what to put in people's minds as well as providing them with the framework within which to evaluate, assess and analyze things. True that people are not naïve to believe everything they are exposed to and the issue is more complex than expressed, but mass media's products constitute a key element of civil society which are aimed at serving the interests of policy makers. Media constitute the soft power which drones on the values of the dominant group and enforces them through consent rather than force. In fact, the news stories generally reiterate the grand narratives that serve the interests of hegemony. According to Gramsci, mass media are important as social institutions that promote the values of the dominant group by producing consensus and manufacturing consent. Similarly, Gitlin (2003) argues that the media control that which it passes to the public, thereby infusing a false consciousness among them.

Media representation of Islam and its culture, therefore, should be analyzed within frameworks of media theories. Hence, we suggest that Said's theory be supplemented with one of the media theories which enable us to understand how public opinion is manipulated. Agenda-setting theory, which refers to the capacity of media to set agendas and to assign importance to an issue through repeated news coverage, is a suitable framework (Severin \& Tankard, 2000, p. 219). According to this theory, repeated media coverage of Muslims as terrorists leads to the belief and acceptance by viewers that they are really terrorists, and hence media generates hate and fear of Muslims. Besides setting the agenda for public discussion, the media also puts in readers' minds what to think, talk about and how. It has an influence on the public perception of issues, and it uses this influence to reinforce orientalist representations of Islam and Muslims.

\section{RESEARCH METHOD}

The paper offers a critical discourse analysis (CDA) of selected examples of media(ted) coverage of Islam and Muslim stories selected from different media sources in the latest years. The texts analysed are selected from a variety of sources, television, newspapers and the Internet using the search terms Islam, Muslims, and Arabs. Such a variety of sources aims at offering a holistic review of the nature and scope of the coverage of Islam and Muslims. The choice of the texts is made on the basis of Topic Modeling, a model for discovering the abstract "topics" that occur in a collection of texts. It helps us identify thematic structures and topics within the texts chosen by focusing on the linguistic discursive landscape which contextualises Muslims and Islam and thus influences their meanings. 
CDA was first developed by the Lancaster school of linguists, an influential figure of which is Fairclough (1995) who has made major contributions to this field of study. CDA makes the point that language plays a crucial role in shaping the way we experience the world, and that language is a tool of domination as well as social practice. Text producers use language in such a way as to shape the hearer/reader's perception of the world. For example, if the aim is to make people hate Islam and Muslims, mass media, which are managed by dominant groups, focus their talk on the threat posed by Islam and Muslims. By linking Islam and Muslims with terrorism, mass media raises the audience's fears and influences them into hating Islam and Muslims.

To uncover such subtle, implicit ideologies, CDA uses different tools such as lexicalization, modality and transitivity. From a CDA perspective, a text reveals the interests served by the text. It helps us understand that a text constructs a version of reality rather than reflects or mirrors reality. It teaches us that the producer of the text constrains possible interpretations of the events through the use of the language.

It is noteworthy that we do not go into details of the texts particularly because it is not feasible with films. Therefore, we only analyse the content and headings using what is referred to as global meanings or topics in Van Dik (2001). Topics play a major role in the analysis because they capture the most important information in the discourse. Also used in the analysis is lexicalization to analyse choice of particular words especially in news that report the Israeli-Palestinian conflict. We believe these two techniques will help us expose the ideological underpinnings of media discourse. Both topics and lexicalisation lend themselves easily to memory and that is why they are important in the analysis.

\section{RESULTS, ANALYSIS AND DISCUSSION}

The main topic that emerges is that Islam is a religion of terror and violence, and that Muslims and Arabs constitute one homogeneous group described as terrorists and killers. In the question of Islam, it is obvious that the global media have overlooked the ethical issues of broadcasting. In the name of "fight against terror", they have launched a concerted campaign against Islam and Muslims. Dozens of documentaries and films have been fabricated which defame Islam and Muslims and portray Muslims as blood thirsty and potential terrorists. As said says, reporters who cover the Muslim world are ignorant about Islam and therefore, develop a distorted image of Islam which they pass on to the masses as if they were the truths. Muslims in Western films and documentaries are exotic, violent, dangerous, always seeking to kill people. Films and documentaries abound in this context.

A very telling case in point is a Danish documentary "Fitna" which contains very shocking images. "Fitna", a 2008 short film, demonstrates that the Qur'an motivates its followers to hate non-Muslims. In a way that makes it appear that the acts of terror by an isolated handful of terrorists are a direct application of the teachings of the Qur'an, the film features selected verses from the Qur'an, followed by media clips and newspaper cuttings which demonstrate acts of terror presumably perpetrated by Muslims. This way, the film links between acts of terrorism and 
Islam, thereby setting the agenda of Muslims as terrorists. The main argument is that Islam is a religion of terror, violence and blood. Also featured in the film is a caricature of the Prophet Muhammad with a bomb on his head in an attempt to describe him as a killer. Besides, the choice of the word "Fitna" as a title is not innocent. It is an Arabic word which denotes disagreement, disorder and chaos with which the film also associates Islam as a religion.

For the people, particularly youths, who cannot obtain information from the mainstream media, the Internet steps in to play the significant role of passing unrestricted information to the masses. Instead offering liberating stories, the Internet constitutes an extension of traditional mass media. It contributes to the process of brainwashing people into believing that Islam has no place in their society. In this context, it was used to host the film "Fitna". The film was released repeatedly on the internet in 2008.

Along the same lines, on September 5, 2014, Gary Cass, head of the Christian Anti-Defamation Commission, argues in a post on his organization's website that the Islamic militant group ISIS had revealed the intentions of all Muslims. The main idea of that post was that Islam has no place in civilized society, thus depicting Islam as a pariah. In Cass's post, Muslims are referred to as would-be terrorists whereas Westerners are associated with civilisation. He writes, for instance, "ISSI ( sic) has done us all a favor,", hence categorizing Westerners as "US", a pronoun which implies its opposite, namely "THEM". The use of the collective pronoun "us" in some of this posting instantiates shared beliefs, viz., those of all Western people who are threatened by a violent Islam. The "US" is inclusive of the West and exclusive of Muslims. In so doing, Islamophobia is a natural outcome and all Muslims are suspects as they constitute the out-group, the pariahs.

In the same year, 2014, a Fox News military analyst compared Islam to Nazism, Fascism and Communism, warning Americans to be wary of individuals who claim to be Muslim American. Similarly, on June 20, 2016, and this time on $\mathrm{CNN}$, an analyst claimed that "the next time you hear of a terror attack -- no matter where it is, no matter what the circumstances -- you will likely think to yourself, 'It's Muslims again.' And you will probably be right." These examples display an Islamophobic discourse, a discourse of fear and hate which works to consolidate a sense of "US" who are threatened by the terrorist "THEM".

Islamophobia has also been deployed to buttress support for Israel, and to cement alliances between Jews and Christians against Muslims. Hence, coverage of conflicts is also subject to deliberate distortion of news and exclusion/suppression of information. In this context, Zaher $(2009$, p. 28$)$ argues that the Israeli-Palestinian conflict is among the main factors that affect the relationship between Arabs and the West. The way it has been covered further shows that media coverage is biased against Arabs and Muslims. A case in point regarding the way it has been covered is from the BBC on 13 February, 2013: 


\section{THREE ISAELIS KILLED BY ROCKET FIRE FROM GAZA, WHERE 13 PALESTINIANS HAVE DIED IN ISRAELI AIR STRIKES SINCE IT KILLED A HAMAS CHIEF ON WEDNESDAY.}

The heading shows clearly that the use of language is not innocent. The writer used the verb "killed" for Israelis which makes them appear victims of an act of terrorism while he used the verb "died" for the Palestinian side which denotes absence of a perpetrator of a terrorist act. The verb "kill" requires a subject who did the killing while "died" does not require a subject. It is an ergative verb the significance of which is to enable the writer to suppress the identity of the agent responsible for the particular process of killing. Even more, it represents the victim of the action as in some way causing the action by which it is affected. Note that when the verb "killed" is used, the question that follows is "who killed them?" while we cannot ask the question of "who died them?" Palestinians are assigned responsibility for killing three Israelis while Israel's responsibility is excluded. Such a choice of words legitimates the use of violence against Palestinians and makes it appear as fight against terror. The foregrounding of the Israeli dead people further serves the process of victimization of Israelis and incrimination of Palestinians.

Therefore, the analysis of the above texts betrays an ideologically laden discourse that distorts the reality of Islam in a way that dichotomizes the world into a positive self-representation and a negative other-representation. Also, the discourses in all the different media types seem to reflect and reinforce each other, thereby reflecting a symbiotic relationship instead of a competing one. The purpose is to demonise Muslims and their religion by casting them in an unfavourable Orientalist light. The analysis also reveals the discursive sources of power, inequality and bias particularly in covering the Israeli Palestinian conflict. The topics of all selected texts denote that Islam and Muslims including Arabs are terrorists. This leads to Islam and Muslims being hated and feared and thus legitimates any action taken against them.

The results obtained fit well with existing research. Representation of Islam and Muslims as a threat to global stability is a discourse that has been at play ever since Western media started the process of coverage. This has been underscored in Said as well as in other researchers who investigated the representations of Islam and Muslims in Western media. Hafez (2000) and Alazzany (2008) also reported biased depictions of Islam and Muslims in their papers. Similarly, Douai and Lauricella (2014) reported that Islam and Muslims are always dealt with from the perspective of terrorism.

It is noteworthy that Arabic and Islamic nations are ironically not responding in the same way. They have not described the actions of the United States towards invasion of Iraq as acts of terrorism, although the death toll has surpassed 100, 000 victims (Lehren \& Tavernise, 2010). Similarly, the NATO airstrikes on civilians in Libya which caused the death of hundreds of innocent noncombatants have not been used by Arabic nations to refer to United States Christians as terrorists. 


\section{CONCLUSION \& SUGGESTIONS}

This paper was about coverage of Islam and Muslims in Western media. It showed with examples that coverage of Islam is not innocent, that "objectivity" and "fairness" that are raised by mass media are far from being true. After all, news about Islam is constructed from a particular ideological point of view which serves the dominant groups and their interests. Such being the case, Islamic nations are branded by Western media as central points of violence and terrorism. While this is hardly new, the 9/11 attacks have led to an increase of media coverage of Islam and Muslims with the terms "Muslim" and "Terrorist" becoming synonymous in many western countries.

Most western media are using the $9 / 11$ attacks to depict Islam as "fundamentalism", "extremism" and "radicalism", thereby manipulating the image of reality to misrepresent Muslims as "terrorists" posing a threat to the western security. The isolated acts of terrorist groups, who kill innocent people, like western hostages, have fed this process of demonization and othering. The isolated attacks are exploited to cause a social anxiety/panic toward Islam and Muslim cultures leading to Islamophobia which is being further reinforced in Trump's America by Trump's immigration ban policy.

Such being the case, the true meaning of Islam and its teachings can never be accurately understood. They can only be understood when the barriers created by the media are removed. Thus, Westerners are called upon to look for true versions of Islam and Muslims in the teaching of Islam. They should go back to primary sources of Islam instead of receiving their stories from second-hand mediated, biased sources. These are the Qu'ran and the Hadiths of the prophet peace be upon him and the great four Imams who have attempted to explain the two Islamic texts, the Qu'ran and the Hadith.

On the part of Muslims and Arabs, to overcome Islamophobia, a number of measures need to be undertaken. Effective initiatives must be made to help nonMuslims get correct Islamic concepts and teachings particularly those of peace and tolerance. First, we must encourage dialogue, and we must all accept and tolerate different cultural and religious values. By integrating difference, it should be underscored that a culturally richer and more open community is the result not a bigot one. Also, open debates should be encouraged in order to make the complexity of the issue transparent and enable different perceptions to take place.

Intercultural education is also an important measure in the direction of overcoming Islamophobia. It can make an important and meaningful contribution to sustainable and tolerant societies. The importance of intercultural education lies in promoting peaceful coexistence, understanding among the peoples of the world. This could be done by creating programmes that encourage dialogue between students of different cultures, beliefs and religions. Also, student exchange programmes are strongly encouraged because they enable students to experience the history and culture of other contries, thereby promoting tolerance and acceptance of difference.

Along with intercultural education, interfaith or interreligious dialogue should be encouraged. Cooperative, constructive and positive interaction between 
people of different religions/faiths at both the individual and institutional levels leads to mutual empowerments of the religions involved. Interfaith dialogue plays an important role in creating a viable, sustaining human society. It also constitutes an alternative to fear, anxiety and hate.

Use of the Internet as a platform for marketing alternative freeing stories are also strongly suggested because of their potential to bring about understanding and tolerance between different religious communities. Particularly young people who are hooked on the internet are encouraged to build stories of love, tolerance and acceptance and to share them with their counterparts in the West.

All in all, on the basis of humanity, we should meet and work together towards the best of our world. We all belong to one race which is the human race; we should know that the durability of our world depends on our acceptance of others, sharing and collaborating, not hating, excluding and exterminating. If mass media manufacture consent and serve hegemony, room for change is also possible with counter-hegemony (Stevenson, 1995, p. 17).

Last, we do recognise some of the shortcomings of the approach adopted in the analysis. First, the data set is small which risks neglecting important patterns. Second, use of CDA has been tainted as lacking academic rigor as the analysis may be influenced by analyst's subjective preconceptions. Thus, we recommend future large-scale studies using large data sets and combining CDA tools with new methodologies and technical solutions to capture the multifacets of media discourse on Islam and Muslims.

\section{REFERENCES}

Alazzany, M. A. O. A. (2008). A critical discourse analysis of the representation of Islam and Muslims following the 9/11 events as reported in The New York Times (Unpublished doctoral dissertation). Universiti Putra Malaysia (UPM), Malaysia.

Alghamdi, E. A. (2015). The representation of Islam in Western media: The coverage of Norway terrorist attacks. International Journal of Applied Linguistics \& English Literature, 4(3), 198-204.

Cottle, S. (2006). Mediatized Conflict: Developments in Media and Conflict Studies. Maidenhead: Open University Press.

Douai, A., \& Lauricella, S. (2014). The 'Terrorism Frame' in 'Neo-Orientalism': Western News and the Sunni-Shia Muslim Sectarian Relations after 9/11. International Journal of Media and Cultural Politics, 10(1), 7-24.

Fairclough, N. (1995). Critical Discourse Analysis. London: Longman.

Gitlin, T. (2003).The Whole World is Watching: Mass Media in the Making and Unmaking of the New left. London: University of California Press. 
Hafez, K. (2000). The West and Islam in the Mass Media: Cornerstones for a New International Culture of Communication in the 21st Century. ZEI Discussion Paper. C 61. Center for European Integration Studies. Bonn, Germanny.

Kempf, W. (2002). Conflict Coverage and Conflict Escalation. In Kempf, W. \& Luostarinen, H. (eds.). (2002). Journalism and the New World Order Vol.2. Göteborg: Nordicom, 59- 72.

Khan, M. (2009). Huntington's Prophecies: A Tribute to an Outstanding Political Genius. Retrieved from Islam Watch: Telling the Truth About Islam: http://islam-watch.org/MA_Khan/Huntington-Prophecies-Tribute-PoliticalGenius.htm

Lehren, A.W., \& Tavernise, S. (2010) A grim portrait of civilian deaths in Iraq. New York Times. Retrieved from: http://www.nytimes.com/2010/10/23/world/middleeast/23casualties.html

Oboler, A. (2016). The normalisation of islamophobia through social media: Facebook. In: Awan Imran (Ed.), Islamophobia in Cyberspace: Hate Crimes Go Viral (pp. 41-62). Routledge, New York.

Poole, E. \& Richardson, J. (2006). Introduction. In E. Poole \& J. Richardson (Eds.), Muslims and the news media (pp. 1-24). London: I.B. Tauris.

Revell, L. (2010). Religious education, conflict and diversity: an exploration of young children's perceptions of Islam. Educational Studies, 36(2), 207-215.

Saeed, A. (2007). Media, Racism and Islamophobia: The Representation of Islam and Muslims in the Media. Sociology Compass, 1(2).

Said, E. (1981). Covering Islam: How the media and the experts determine how we see the rest of the world. New York: Pantheon Books.

Schrag, Robert L., \& Manoocher N. Javidi. (1997). Through a glass darkly: American media images of Middle Eastern cultures and their potential impact on young people." In U.S. Media and the Middle East, ed. Yahya R. Kamalipour, pp. 212-221. Westport: Praeger.

Severin, W. J., \& Tankard, J. W. (2000). Communication theories: Origins, methods, and uses in the mass media ( $5^{\text {th }}$ ed.). New York: Longman.

Stevenson, N., (1995). Understanding Media Cultures: Social Theory and Mass Communication. London: Sage.

Törnberg, A., \& Törnberg, P. (2016). Muslims in social media discourse: Combining topic modeling and critical discourse analysis. Discourse, Context and Media, 13, 132-142.

Unchit, Sumanawika. (2016). A CDA of Thai and American Music Radio Programs in Terms of the Influence of the Language of American Culture on the Language of Thai Culture. Journal of English Language Teaching and Linguistics, 1(2), 2016. DOI: http://dx.doi.org/10.21462/jeltl.v1i2.22

Van Dijk, T. (1991). Racism and the press. London: Sage.

Van Dijk, T. (1998). Ideology: a multidisciplinary approach. London: Sage.

Wanta, W., \& Wu, Y. C. (1992). Interpersonal communication and the agendasetting process. Journalism Quarterly, 69, 847-855. 
Zaher, A. (2009). A Critical Discourse Analysis of News Reports on the Israeli/Palestinian Conflict in Selected Arab and Western Newspapers. Nottingham Trent University.

http://irep.ntu.ac.uk:1801/webclient/StreamGate?folder_id=0\&dvs=14318829 50396 704. (25 November, 2014).

Author:

Bouchaib Benzehaf

Faculty of Letters and Human Sciences

Chouaib Doukkali University,

El Jadida, Morocco

bbenz841@gmail.com 